\title{
MENURUNNYA KADAR HEMOGLOBIN PADA PENDERITA END STAGE RENAL DISEASE (ESRD) YANG MENJALANI HEMODIALISIS DI KOTA MALANG
}

\author{
Wiwik Agustina ${ }^{1}$, Agus Eko Purnomo ${ }^{2}$ \\ STIKES Maharani Malang ${ }^{1}$ \\ Email : nerswika@gmail.com
}

\begin{abstract}
Incidence of kidney failure in Indonesia has increased by $20 \%$ annually, an estimated 70,000 people in 2011, 4,000-5,000 people are detected with end-stages renal failure and undergoing hemodialysis. The hemodialysis process causes some blood trapped or left in the hemodialysis device, some red blood cells are damaged and folic acid decreases. The aims of this study was to know the difference of hemoglobin ( $\mathrm{Hb})$ profile in End Stages Renal Disease (ESRD) patients based on duration of hemodialysis at $R S$ " $S$ " Malang. The research method used a comparative design with a sample of 100 respondents. Anova test showed the difference of $\mathrm{Hb}$ level profile in ESRD patients based on duration of hemodialysis from 1 year up to 10 years $(p=0,03 ; \alpha=0,05)$, which means that the longer the hemodialysis then the Hb level decreases. Anemia is a complication of ESRD, the decrease in $\mathrm{Hb}$ resulting from disruption of the production of the hormone erythropoetin, in addition hemodialysis process also exacerbates the degree of anemia where some red blood cells trapped in hemodialysis, red blood cells are damaged, and folic acid decreased due to dissolved in fluid dialysis. Furthermore, it is necessary to examine related factors that cause the decrease in $\mathrm{Hb}$ in patientss with ESRD with hemodialysis therapy both intrinsic and extrinsic factors.
\end{abstract}

Keywords: hemoglobin, ESRD, hemodialysis

\section{PENDAHULUAN}

End Stage Renal Disease (ESRD) merupakan suatu proses kerusakan sel-sel ginjal dengan rentang waktu lebih dari 3 bulan. ESRD dapat menimbulkan gejala berupa laju filtrasi glomerular di bawah $60 \mathrm{~mL} / \mathrm{men} / 1.73 \mathrm{~m} 2$, atau di atas nilai tersebut namun disertai dengan kelainan sedimen urin. Proses perjalanan penyakit dari ESRD disebabkan oleh berbagai etiologi yang secara progresif menurunkan fungsi dari ginjal, sehingga lama-kelamaan ginjal akan mengalami kehilangan fungsinya yang disebut dengan gagal ginjal. Kerusakan sel ginjal bersifat 
irreversible, pada end stage renal disease diperlukan terapi transplantasi maupun dialysis (Levine et al, 2008; Suwitra, 2014)

Penyakit Tidak Menular (PTM) merupakan penyebab kematian di Indonesia sebesar 59\%, yang salah satunya adalah ESRD. Insiden gagal ginjal di Indonesia cukup tinggi, dengan angka peningkatan mencapai 20\% (Balitbangkes, 2010). Pengobatan ESRD membutuhkan biaya terapi yang sangat besar. ESRD adalah penyakit katastropik nomor dua yang paling tinggi biaya pengobatannya setelah penyakit jantung. Hemodialisis merupakan terapi yang banyak dipilih oleh penderita ESRD menurut National Kidney and Urologic Diseases Information Clearing House. Hemodialis merupakan suatu tindakan terapi dengan tujuan membersihkan darah menggunakan mesin hemodialisa dan berbagai alat pendukunya, dimana air secara pasif melewati darah menuju kompartemen cairan dialisat menembus membran semi permeabel dalam dializer dan partikel terlarut/salut mengalami proses difusi. Selama proses terapi hemodialisis, berapa darah terjebak atau tertinggal di alat hemodialisa, selain itu sebagian sel darah merah mengalami kerusakan dan terjadi penurunan asam folat (Corwin , 2000; Daurgirdas et al., 2014; Depkes, 2018; Hanif, 2009).

Di Amerika Serikat prevalensi penderita ESRD yang memilih terapi melalui hemodialisis terus mengalami peningkatan yaitu sekitar 320.000 orang kemudian mengalami peningkatan menjadi 650.000 orang pada tahun 2010 (Kresnawan, 2007). Menurut hasil Riset Kesehatan Dasar (Riskesdas) tahun 2013, menjelaskan bahwa prevalensi ESRD di Indonesia berdasarkan diagnosis dokter sebesar 0,2\%. Menurut Persatuan Nefrologi Indonesia (Pernefri) diperkirakan ada 70.000 penderita gagal ginjal di Indonesia pada tahun 2011, namun yang terdeteksi gagal ginjal stadium akhir yang menjalani terapi hemodialisis hanya $4.000-5.000$ orang.

Survei awal di ruang hemodialisa RS "S" Malang di dapatkan 19.398 kunjungan di tahun 2015, 24.904 kunjungan di tahun 2016 dan 7.633 kunjungan pada bulan Januari - Maret 2017. Dengan demikian peneliti ingin mengetahui perbedaan profil kadar hemoglobin $(\mathrm{Hb})$ pada penderita End Stage Renal Disease (ESRD) berdasarkan lamanya menjalani hemodialisis di kota Malang.

\section{METODE PENELITIAN}

Desain komparatif digunakan dalam Penelitian ini, data dihimpun dengan pendekatan cross sectional. Populasi meliputi semua penderita ESRD yang menjalani hemodialisis Di RS "S" kota Malang di tahun 2017 sejumlah 7.633 orang, sampel sejumlah 100 orang yang diambil secara kuota sampling. Data diambil melalui rekam medis penderita, selanjutnya data dianalisis menggunakan uji beda one way anova. 


\section{HASIL DAN PEMBAHASAN}

Tabel 1. Jenis kelamin responden

\begin{tabular}{lcc}
\hline \multicolumn{1}{c}{ Jenis Kelamin } & Jumlah & Prosentase \\
\hline Laki-laki & 50 & 50 \\
Perempuan & 50 & 50 \\
\hline Total & 100 & 100 \\
\hline
\end{tabular}

Berdasarkan tabel di atas karakteristik penderita ESRD di RS"S" kota Malang berdasarkan jenis kelamin separuhnya adalah perempuan

Tabel 2. Usia responden

\begin{tabular}{|c|c|c|}
\hline Usia & Jumlah & Prosentase \\
\hline 26-35 tahun & 13 & 13 \\
\hline 36-45 tahun & 19 & 19 \\
\hline 46-55 tahun & 51 & 51 \\
\hline 56-65 tahun & 17 & 17 \\
\hline Total & 100 & 100 \\
\hline
\end{tabular}

Berdasarkan tabel di atas karakteristik penderita ESRD di RS "S" kota Malang berdasarkan usia, hampir sebagian besar berusia 46-55 tahun.

Tabel 3. Lamanya menjalani hemodialisis

\begin{tabular}{|c|c|c|c|}
\hline \multirow{2}{*}{$\begin{array}{l}\text { Lama menjalani hemodialisis } \\
\text { (tahun) }\end{array}$} & \multicolumn{2}{|c|}{ Jumlah Responden } & \multirow[b]{2}{*}{ Prosentase } \\
\hline & $\mathrm{P}$ & $\mathrm{L}$ & \\
\hline 1 tahun & 5 & 5 & 10 \\
\hline 2 tahun & 5 & 5 & 10 \\
\hline 3 tahun & 5 & 5 & 10 \\
\hline 4 tahun & 5 & 5 & 10 \\
\hline 5 tahun & 5 & 5 & 10 \\
\hline 6 tahun & 5 & 5 & 10 \\
\hline 7 tahun & 5 & 5 & 10 \\
\hline 8 tahun & 5 & 5 & 10 \\
\hline 9 tahun & 5 & 5 & 10 \\
\hline 10 tahun & 5 & 5 & 10 \\
\hline Total & 50 & 50 & 100 \\
\hline
\end{tabular}

Tabel 4. Kadar $\mathrm{Hb}$ responden

\begin{tabular}{llll}
\hline \multirow{2}{*}{$\begin{array}{l}\text { Lama } \\
\text { hemodialisis }\end{array}$} & \multicolumn{2}{c}{ Rata-rata Hb menurut jenis kelamin $(\mathrm{gr} / \mathrm{dl})$} & Rata-rata \\
\cline { 2 - 3 } & Laki-laki & Perempuan & Hb $(\mathrm{gr} / \mathrm{dl})$ \\
\hline 1 & 9.7 & 10.38 & 10.04 \\
2 & 9.10 & 10.52 & 9.81 \\
3 & 8.89 & 9.82 & 9.36 \\
4 & 9.56 & 9.28 & 9.42 \\
\hline
\end{tabular}




\begin{tabular}{llll}
\hline 5 & 8.82 & 10.74 & 9.78 \\
6 & 9.56 & 9.44 & 9.50 \\
7 & 8.64 & 9.24 & 8.94 \\
8 & 8.46 & 9.36 & 8.91 \\
9 & 8.30 & 7.74 & 8.02 \\
10 & 8.05 & 9.16 & 8.61 \\
Rata-rata & 8.91 & 9.57 & 9.24 \\
\hline
\end{tabular}

Tabel 5. Hasil analisi data

\begin{tabular}{|c|c|c|c|c|c|c|}
\hline \multirow{2}{*}{$\begin{array}{l}\text { Kelompok } \\
1 \text { th }\end{array}$} & \multirow{2}{*}{$\begin{array}{l}\mathbf{n} \\
10\end{array}$} & \multicolumn{2}{|c|}{ Mean \pm Stan.Dev. } & \multirow{2}{*}{$\begin{array}{l}\mathbf{p} \\
0,03\end{array}$} & \multirow{2}{*}{$\begin{array}{l}\mathbf{r} \\
-0,364\end{array}$} & \multirow{2}{*}{$\begin{array}{l}\mathbf{R}^{2} \\
13,3\end{array}$} \\
\hline & & 10,04 & $\pm 0,9^{\text {abcdefghj }}$ & & & \\
\hline 2 th & 10 & 9,8 & $\pm 1,5^{\text {abcdefghij }}$ & & & \\
\hline 3 th & 10 & 9,4 & $\pm 1,3^{\text {abcdefghij }}$ & & & \\
\hline 4 th & 10 & 9,4 & $\pm 1,2^{\text {abcdefghij }}$ & & & \\
\hline 5 th & 10 & 9,8 & $\pm 1,5^{\text {abcdefghij }}$ & & & \\
\hline 6 th & 10 & 9,5 & $\pm 1,5^{\text {abcdefghij }}$ & & & \\
\hline 7 th & 10 & 8,9 & $\pm 1^{\text {abcdefghij }}$ & & & \\
\hline 8 th & 10 & 8,9 & $\pm 1,2^{\text {abcdefghij }}$ & & & \\
\hline 9 th & 10 & 8 & $\pm 1,5^{\text {bcdefghij }}$ & & & \\
\hline 10 th & 10 & 8,6 & $\pm 1,4^{\text {abcdefghij }}$ & & & \\
\hline
\end{tabular}

Keterangan: $p>0.05$ tidak terdapat perbedaan, $p<0.05$ terdapa perbedaan. Pada masing-masing kelompok jika pada mean \pm sd terdapat huruf yang berbeda berarti ada perbedaan yang bermakna (nilai $\mathrm{p}<0.05$ ) dan bila terdapat huruf yang sama berarti tidak ada perbedaan yang bermakna (nilai $\mathrm{p}>0.05$ ).

Penelitian ini dilakukan untuk melihat apakah ada perbedaan profil kadar hemoglobin $(\mathrm{Hb})$ pada penderita End Stage Renal Disease (ESRD) berdasarkan lamanya menjalani hemodialisis, yang dilibatkan dalam penelitian ini adalah penderita ESRD yang menjalani hemodialisis selama 1 tahun sampai dengan 10 tahun.

Karakteristik usia dari 100 responden didapatkan $51 \%$ berusia $46-55$ tahun yang merupakan masa lansia awal. Menurut Tamtomo (2016) umur 30 tahun fungsi fisiologis ginjal mulai mengalami penurunan dan usia 60 tahun fungsi ginjal tinggal $50 \%$, penurunan fungsi ginjal ini disebabkan oleh penurunan populasi nefron dan ketidakmampuan sel-sel ginjal untuk beregenerasi. Hal ini sejalan dengan karakteristik reponden dimana pada usia 26-35 tahun sudah terjadi kasus ESRD sebesar $13 \%$. 
Hasil analisis statistik One-way Anova Test didapatkan nilai $\mathrm{p}=0.03$ dengan $\alpha=0,05$ maka hal ini menunjukkan bahwa terdapat perbedaan profil kadar $\mathrm{Hb}$ pada penderita ESRD berdasarkan lamanya menjalani hemodialisis mulai 1 tahun sampai dengan 10 tahun. Berdasarkan mean kadar $\mathrm{Hb}$ pada responden laki-laki kadar $\mathrm{Hb}$ tertinggi terdapat pada lama hemodialisis 1 tahun sebesar 9,7 gr/dl terendah terdapat pada lama hemodialisis 10 tahun sebesar 8,05 gr/dl dan rerata kadar $\mathrm{Hb}$ pada penderita yang menjalani hemodialisis selama 1 tahun sampai dengan 10 tahun adalah 8,91 gr/dl, sedangkan pada responden perempuan kadar $\mathrm{Hb}$ tertinggi terdapat pada lama hemodialisis 1 tahun sebesar 10,74 gr/dl terendah terdapat pada lama hemodialisis 9 tahun sebesar 8,02 gr/dl dan rata-rata kadar $\mathrm{Hb}$ pada penderita yang menjalani hemodialisis selama 1 tahun sampai dengan 10 tahun adalah 9,57 gr/dl. Dengan demikian dapat disimpulkan bahwa responden laki-laki dan perempuan mengalami anemia. Hal ini sesuai dengan pernyataan Suwitra (2014) bahwa anemia terjadi pada $80-90 \%$ penderita penyakit ESRD.

Uji korelasi dengan menggunakan Pearson Test menunjukkan adanya hubungan antara lama hemodialisis dengan terjadinya anemia, analisis kekuatan hubungan menunjukkan tingkat yang lemah antara kadar $\mathrm{Hb}$ dengan lamanya hemodialisis dengan nilai $\mathrm{r}$ sebesar -0,364, arah korelasi menunjukkan nilai negatif yaitu berlawanan arah yang berarti kadar $\mathrm{Hb}$ semakin mengalami penurunan seiring semakin lamanya waktu menjalani hemodialisis.

Keadaan klinis gagal ginjal ditandai dengan penurunan fungsi yang irreversible, pada stadium akhir diperlukan terapi pengganti ginjal, yaitu transplantasi ginjal atau dialisis. Indonesia merupakan salah satu negara dengan tingkat gagal ginjal yang cukup tinggi. Salah satu komplikasi dari ESRD adalah anemia, dimana kadar $\mathrm{Hb}$ mengalami penurunan (Balitbangkes, 2010; Mary LT, 2012).

Penurunan kadar $\mathrm{Hb}$ diakibatkan terganggunya produksi hormon eritropoetin. Eritropoitin merupakan hormon glikoprotein yang merupakan stimulan eritropoiesis, sebuah pathway metabolisme yang menghasilkan eritrosit. Sintesis dominan eritropoitin terjadi pada sel di area interstitial peritubular ginjal, selain hati dan otak. Sel-sel ini memproduksi dan melepaskan eritropoetin ketika tingkat oksigen sangat rendah. Tingkat oksigen yang rendah dimungkinkan mengindikasikan anemia, dimana jumlah sel darah merah mengalami penurunan, sehingga hemoglobin yang membawa oksigen keseluruh tubuh juga mengalami penurunan (Mary LT, 2012).

Faktor-faktor lain yang memperberat munculnya anemia diantaranya perdarahan akibat trombopati, zat inhibitor eritropoesis, hiperparatiroid sekunder, anemia hemolitik akibat dari mikroangiopati, darah yang terjebak atau tertinggal di alat hemodialisa, kehilangan darah akibat pengambilan sampel darah untuk pemeriksaan laboratorium, defisiensi zat besi dan zat nutrisi lainnya (Hanif, 2009). 
hemodialisis merupakan tindakan untuk memperbaiki kelainan biokimia darah yang terjadi akibat terganggunya fungsi dari ginjal, tindakan ini membutuhkan mesin hemodialisis.

Metode ini merupakan salah satu bentuk intervensi pengganti ginjal (renal replacement therapy/RRT) dan hanya menggantikan sebagian dari fungsi ginjal. Tindakan hemodialisis saat ini mengalami perkembangan yang pesat, tetapi masih banyak penderita mengalami masalah medis saat menjalani hemodialisis. Gangguan hemodinamik merupakan salah satu komplikasi yang paling umum timbul pada penderita yang menjalani terapi hemodialisis (Daurgirdas et al., 2014; Landry dan Oliver, 2006).

Penurunan kadar asam folat biasa dialami oleh penderita yang menjali terapi hemodialisis akibat asam folat terlarut dalam dialysis fluid, inilah salah satu penyebab terjadinya anemia. Kadar $\mathrm{Hb}$ pada penderita dengan hemodialisis sejumlah 4-15 g/dl dan rata-rata $8 \mathrm{~g} / \mathrm{dl}$ (Hanif, 2009).

Pada penelitian terdahulu yang menggunakan metode bio-assay untuk menganalisis perbedaan antara penderita anemia tanpa penyakit ESRD dengan penderita anemia menderita ESRD, menunjukkan anemia pada penderita ESRD mengalami peningkatan konsentrasi eritropoetin serum yang tidak adekuat. Inflamasi kronik, menurunkan produksi eritrosit dengan dampak lain terjadi defisiensi erotropoetin. Proses inflamasi seperti penyakit pielonefritis kronik, glomerulonefritis, dan reumatologi, yang biasanya merupakan akibat pada ESRD, penderita dialisis rentan mengalami inflamasi yang terjadi akibat efek imunosupresif. Defisiensi eritropoetin relatif pada penderita ESRD dapat berespon terhadap penurunan fungsi sel glomerulus. Selain itu, telah terbukti juga bahwa toxin uremik juga dapat menginaktifkan eritopoietin atau menekan respon sumsum tulang terhadap eritropoietin (Hartanto, 2012).

Dalam hal penurunan kadar eritropoetin, proses penghambatan respon sel prekursor eritrosit terhadap eritropoetin diduga sebagai pemicu dari eritropoesis yang tidak adekuat pada penderita dengan uremia. Terdapat toxin uremia yang mensupresi proses eritropoesis yang dapat dilihat melalui proses hematologi pada penderita ESRD setelah menjalani terapi hemodialisis. Substansi penghambat eritropoesis diantaranya meliputi spermin, spermidin, poliamin, dan PTH. Peningkatan kadar spermidin dan spermin serum pada penderita ESRD tidak hanya memberi efek penghambatan pada eritropoesis saja, tetapi juga dapat menghambat trombopoesis dan granulopoesis. Karena ketidakspesifikan, trombositopenia, dan leukopenia bukan merupakan karakteristik dari uremia, maka dapat disimpulkan bahwa spermidin dan spermin tidak memiliki fungsi yang signifikan pada patogenesis anemia pada ESRD (Singh, 2008).

Untuk mengetahui seberapa jauh pengaruh lamanya hemodialisis terhadap kadar $\mathrm{Hb}$ pada penderita ESRD dilakukan uji regresi linier dan didapatkan nilai $\mathrm{R}^{2}=13,3$; yang artinya lama hemodialisis memiliki pengaruh sebesar $13,3 \%$ 
terhadap penurunan kadar $\mathrm{Hb}$. Selain hemodialisis masih banyak faktor lain yang menyebabkan turunnya kadar $\mathrm{Hb}$ dintaranya adalah kecukupan besi dalam tubuh, metabolisme besi dalam tubuh, gizi, kehilangan darah, masa hidup eritrosit yang memendek akibat kondisi uremia, defisiensi asam folat, serta proses inflamasi akut dan kronik, hiperparatiroid berat dengan konsekuensi fibrosis sumsum tulang Selain itu kondisi komorbiditas seperti hemoglobinopati dapat memperburuk anemia (Nurdiana, 2015; Longo et al, 2012; Suwitra, 2014; Zarianis, 2006).

\section{KESIMPULAN}

Terdapat perbedaan profil kadar hemoglobin $(\mathrm{Hb})$ pada penderita Gagal Ginjal Kronis (ESRD) berdasarkan lamanya menjalani hemodialisis di RS "S" kota Malang dimana semakin lama menjalani hemodialisis maka kadar Hb semakin turun.

Dari hasil penelitian ini disarankan untuk dilakukan penelitian lebih lanjut terkait faktor-faktor yang menyebabkan turunnya $\mathrm{Hb}$ pada penderita ESRD dengan terapi hemodialisis baik faktor intrinsik dan ekstrinsik. Selanjutnya dilakukan analisis faktor yang paling dominan dalam menyebabkan tununya kadar $\mathrm{Hb}$

\section{DAFTAR PUSTAKA}

Badan Penelitian dan Pengembangan Kesehatan RI (Balitbangkes). 2010. Laporan Hasil Riset Kesehatan Dasar (Riskesdas) Indonesian tahun 2010. Jakarta: Kementrian Kesehatan Republik Indonesia.

Corwin, Elizabeth J. 2000. Buku Saku Pathofisiologi. Jakarta: EGC

Daugirdas, J.T., Blake, P.G., Ing, T.S. 2014. Handbook of Dialysis. 5th ed. Phildelphia. Lipincott William \& Wilkins.

Hanif, H.M. Edial. 2009. Resiko Anemia pada Penyakit Ginjal Kronik. Diunduh dari URL:http://www.jantunghipertensi.com/ginjal/112.pdf

Hartanto H, Susi N, Wulansari P, Mahanani DA, 2012. editors: Patofisiologi konsep klinis proses-proses penyakit. 6nd ed. Jakarta: EGC

http://www.depkes.go.id/article/print/18030700007/cegah-dan-kendalikanpenyakit-ginjal-dengan-cerdik-dan-patuh.html. diakses tanggal 15 Agustus 2018

Kresnawan, T., Markun. 2007. Diet Rendah protein dan Penggunaan Protein Nabati pada penyakit Ginjal kronik, Divisi Ginjal Hipertensi Bagian penyakit Dalam : FKUI-RSCM.

Landry, D.W., and Oliver, J.A. 2006. Blood pressure instability during hemodialysis. Kid Int: 69, 1710-11.

Levine et al. 2008. Guidelines for the management of chronic kidney disease. Canadian Medical Association Journal. 179:11 
Mary L.T. 2012. Clinical Hematology. Lippincott Williams \& Wilkins. Philadelphia.

Nurdiana, 2015. Factors Affecting The Level Of Hemoglobin On Junior High School Children On Coast Regional District Of Nort Lombok. BIOTA: Jurnal Tadris IPA Biologi FITK IAIN Mataram Vol 8. No 1

Pernefri.2011. $4^{\text {th }}$ Report Of Indonesian Renal Registry. http://www.pernefriinasn.org/Laporan/4th\%20Annual\%20Report\%20Of\%20IRR\%202011.p df

Price, S.A dan Wilson. 2014. Patofisiologi Konsep Klinis Proses-Proses Penyakit. Jakarta : EGC

Riskesdas.2013.http://www.depkes.go.id/resources/download/general/Hasil\%20Ri skesdas \%202013. diakses tanggal 15 Agustus 2018

Singh AK. Anemia of Chronic Kidney Disease. Clin J Am 2008; vol. 3

Suwitra, K. 2014. Penyakit Gagal Ginjal Kronis. Buku Ajar Ilmu Penyakit Dalam. Edisi ke-5. Jakarta : Internal publishing.

Tamtomo DG. 2016. Perubahan Anatomik Organ Tubuh Pada Penuaan. https://library.uns.ac.id/perubahan-anatomik-organ-tubuh-pada-penuaan/ diakses tanggal 25 Agustus 2018

Zarianis, 2006. Efek Suplementasi Besi Vitamin C dan Vitamin C terhadap Kadar Hemoglobin Anak Sekolah Dasar yang Anemia Di Kecamatan Sayung Kabupaten Demak.Tesis Program Magister Gizi Masyarakat Universitas Diponegoro.http://eprints.Undip.ac.id/15967/1/Zarianis.pdf 